\title{
Accountability: a necessity to pro-poor service delivery in Municipal Councils in Uganda
}

\author{
David Mwesigwa $^{1^{*}}$, Ibrahim Abiodun Oladapo ${ }^{2}$
}

Senior Lecturer, Faculty of Management Sciences, Lira University, Northern Uganda ${ }^{1 *}$

Department of Economics, College of Business Administration, Imam Abdulrahman Bin Faisal

University, Dammam, Kingdom of Saudi Arabia ${ }^{2}$

mwesigwadavid22@gmail.com ${ }^{1^{*}}$, iaoladapo@iau.edu.sa ${ }^{2}$

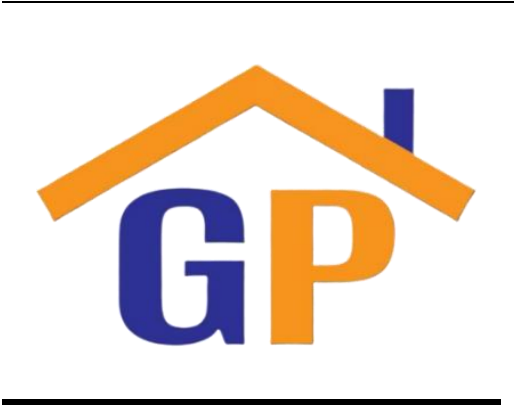

Article History

Received on 16 December 2020

Revised on 12 January 2021

Accepted on 14 January 2021

\begin{abstract}
Purpose: There is mounting fear that the present-day Local Government managers do not appropriately respond to pro-poor service delivery. Yet, the number of people lacking access to quality services is swelling. This fault has placed a growing burden on Local Governments to enhance local councilors' political accountability by ensuring that the basic services are made delivered to citizens with accountability. Given the different challenges and observed shortage of political accountability in Uganda, this study examined the contribution of political accountability towards achieving pro-poor service delivery in a Ugandan Municipality.
\end{abstract}

Research methodology: Using five Focus group discussions, perspectives on accountability are debated as a foundation for improving service delivery.

Limitation: The study covers only Uganda and may not easily be generalised to other countries.

Results: Results indicate that political accountability is key to implementing a municipal development plan.

Contribution: The study contributes to knowledge so that handson accountability holds potential and requires more consideration as a means to assimilate learning-based methods and role-players network to back up the delivery of pro-poor services. It is proposed that local councilors become more responsive to meet the growing need for pro-poor service delivery in a Municipal council.

Keywords: Accountability, Pro-poor service delivery, Horizontal, Vertical, Diagonal

How to cite: Mwesigwa, D., \& Oladapo, I. A. (2021). Accountability: a necessity to pro-poor service delivery in Municipal Councils in Uganda. Journal of Governance and Accountability Studies, 1(1), 43-54.

\section{Introduction}

The degree to which accountability can influence Municipal service delivery in the Less-Developing Countries (LDCs) is drawing much consideration among academics and legislators worldwide. This consideration arises from several concerns. The first concern is that there are indications that trends of service delivery are taking a rapid shift given the simplification of organisational processes and arrangements (Bolgherini et al., 2019:112), collaborations between public and private sectors (Casady et al 2019:2), sporadic urbanisation (BIdandi \& Williams, 2017:2), as well as demographic transition experiencing significant reforms in local Municipalities (Eastwood \& Lipton, 2011:9). The inference of these considerations is that it is no longer enough for local Municipalities to provide adequate and quality services to meet the dynamic urban population. The second concern is that some Municipalities in Uganda have failed to provide services with the profession and skill necessary (Mbazira, 2013:252). Consequently, there is a wider deficit in service delivery in almost every sector 
ranging from physical infrastructure, including roads and bridges, hospitals, and schools to social infrastructure (Musenze et al 2014:93).

Municipalities in Uganda have to endure endless condemnations for the view that their service delivery approach has little or no significance to the social and economic needs of their residents (Nastar et al 2019:358), which results in the provision of inadequate or low-quality services or both. Indications from previous research revealed that the high frequency of service delivery protests suffered by Municipalities is a consequence of the inadequacy and shortage of certain urban services essential to an urban resident (Mbazira, 2013). Proof supporting this statement demonstrates that out of approximately 35 Municipalities in the country, none had a favourable road network, maybe as a result of their deficiency of necessary funds for providing such services, until the World Bank offered support through the Uganda support for municipal infrastructure (Mwesigwa, 2018). Likewise, a study conducted by the UN-Habitat (2015:8) notes that approximately several urban authorities in developing nations, including Municipalities in Uganda, are both under-resourced and lack sustainable local revenue sources.

According to Kayiwa et al (2020:2), several urban residents who access the basic urban services are not pleased with the quality of service. For those who access quality urban services, the services are never adequate regardless of having met all their tax obligations. Similarly, Mwesigwa and Mubangizi (2015) reveal apprehensions regarding local councilors' ability and or mayor to respond to some residents' petitions concerning the ever-deteriorating quality basic services, for example, roads, street lighting, and basic sanitation. The above study also reveals acute shortages in political interaction between local councillors and or mayors and the residents; this is made worse by lack of regular communication, dearth of accountability, and scarcity in both practical and supervisory abilities. The outcomes of this research corroborated with those of comparative analyses, for example, those of Nattabi (2020). The scope of deficiency of political obligation as exposed in these researches further maintained the view that many Municipalities in Uganda were faced with scarcity of sources of revenue and where such sources existed. The government decided to centralise them through the central agency (Uganda Revenue Authority).

The idea of service delivery is challenging to the conventional municipal governance theory and attracts questions regarding the significance of creating several Municipalities in Uganda. Normally, it is the prospect of municipal residents, including Uganda, in several nations to enjoy decent services better than their rural counterparts. As stated by McConville et al. (2019:586), this prospect is coherent from the view of urban life, which demands that municipal residents be offered descent services such as roads, street lighting, healthcare, education, sanitation, and security. Nonetheless, with the present-day challenge where a dearth of accountability translates into low quality or inadequate service, this view remains a deception for some municipal residents and visitors. Considering accountability in Uganda, as deliberated, this article offers a perspective of enhancing accountability from the view of pro-poor service delivery. While strategies (such as citizen participation, accountability and transparency) have been put forth by academics, such as Musenze and Mayende (2020:2) as well as various civil society organisations that underscore governance to advance views on municipal service delivery, none appear applicable to the Ugandan circumstances where conditions of governance are different.

In Uganda, available studies (such as Birungi and Colbourn, 2019:372) on accountability are few. Such studies mainly list different general abilities and attributes (such as position, influence, and interest) electorates demand from the leadership at various levels. However, they fail to discuss key components of accountability and how accountability is related, contributes to, and impacts pro-poor service delivery in a local Municipality.

The central focus of this article is the prevalent condition of shortage of accountability among some municipal service providers in Uganda, which is one of the key causal factors to poor service delivery in much of the country and beyond. For example, in China, accountability is very key in every aspect of governance, including rural poverty reduction strategies (Zhou \& Cai, 2020:287; Wu \& Christensen, 2020:5). Also, studies reveal a shift from monetary accountability to accountability due to its significance to the European Union (Steinbach, 2019:1355). From this literature, there are 
pointers that the challenge of poor service delivery in Uganda is by its nature organisational. Some service providers are not responsible in their quest to make available the necessary services such as road construction and maintenance. This condition is a big test for the significance of local Municipalities (many of which are already to attain city status), and as a consequence, demands immediate consideration. Considering this challenge, this article explores the means by which the accountability of service providers in the local Municipality can be enhanced. Consequently, this study's main objective is to suggest a model of municipal service providers in Uganda. In attaining this objective, the following research questions will be answered: (a) what are the techniques of enhancing accountability at a municipal council? (b) What are the dimensions of accountability in Municipalities in Uganda? (c) What value does accountability bring to pro-poor service delivery? And, (c) what are the implications of accountability for pro-poor service delivery in a municipal council?

\section{Literature review}

The necessity of accountability regarding pro-poor service delivery is enormous and has been approached differently by different authors though none has focused on Municipal councils in the Ugandan context.

\subsection{The concept of accountability}

There is a certain degree of confusion over the concept of accountability. It is a term used in a range of contexts with different meanings, and if not careful, the definition can lack clarity as an operational concept (Mir et al 2020:124). For example, some researchers recognise being accountable for being responsible, a perception that has been criticised for being too narrow (Ogentho et al 2020). Accountability is answerability or liability; these are both applicable in a range of contexts (Bryld et al 2020). According to Modoi (2015), the notion of accountability refers to an individual or establishment's obligation to answer for its actions, admit blame for them, and expose the outcomes in a crystal clear way. The above author adds that accountability embraces the obligation for funds or other assigned assets. It further refers to guaranteeing that administrators in governmental, private and non-governmental or voluntary sector organisations are liable for their activities and reparations when responsibilities and obligations are not discharged. The Republic of Uganda (Government of Uganda, $1995)$ provides that whoever holds any public office, shall do so in trust for the citizens of Uganda.

Consequently, every person entrusted in any position of leadership and or accountability shall be answerable to the people of Uganda in the exercise of their actions. The same Constitution further provides that every legal means shall be applied to uncover, combat, and eliminate dishonesty, misapplication, or mismanagement of authority by those entrusted with governmental or other public offices. This requirement is achieved through many established and individual government service ideals informing of policies, laws, rules, guidelines, codes of conduct and standing orders. In a similar tone, Article 17(I) (i) of the Uganda Constitution states that every citizen is accountable in fighting dishonesty and misappropriation and or wastage of government resources.

In practice, accountability is demonstrated in various ways and at different levels. The different perspectives include presenting periodic performance reports, presenting financial reports, conducting internal and external audits, conducting staff performance appraisals, and conducting disciplinary measures.

\subsection{Presentation of periodic performance Reports}

Performance is defined as employees' contribution to make them attain goals (Herbert et al 2000). It is the measure of what an organization has accomplished with respect to the process, results, relevance and success Uganda National Development Program (1995). To others, performance denotes whether an official executes his/her duties and responsibilities well (Choge et al., 2014). Obtained evidence indicates municipal councils in Uganda do not present quarterly performance reports save for the annual reports since none of the supervisors appears to pursue the reports as a routine feedback. According to Su et al (2019:438), there is a close link between progressive feedback of a manager and the performance of employees although this is, in part, facilitated by employees pursuing the feedback. In the case of Ugandan Municipalities, it is injurious seeing that certain eventualities call 
for immediate attention and if the council only considers the annual report then it becomes too late to address such issues. For example, staff in the department of environmental and sanitation in many Municipalities have issues that require immediate but had to wait for the year end to have them reported by the head of sector when it was too late.

\subsection{Presentation of financial reports}

Municipalities in Uganda apply both internal audit and external audit. The internal audit department conducts quarterly audits to identify issues that may call for instantaneous attention before the external audit is conducted, usually at the end of the year. The external audit is held once a year by the office of the auditor general. The two audits allow a municipal council to examine both quarterly financial reports and annual financial reports of a municipal council. The biggest shortcoming with these presentations is that the financial reports are presented in a financial language which can be understood by less than $20 \%$ of the council. This situation is not different from what was revealed in a study Kassem (2019:2008), who found that arrangements for financial reporting scam are committed and covered by those otherwise responsible in Egypt. As a result, the presentation of financial reports to the municipal council has become a ritual rather than making scrutiny and recommendations based on informed analysis.

\subsection{Conduct of internal and external audits}

Internal auditing is an independent appraisal function established within a municipal council to examine and evaluate its activities as a service to the citizens. The objective of internal auditing is to assist a municipal council in discharging of their responsibilities effectively. Internal auditing furnishes them with analyses, appraisals, recommendations, advice and information concerning the activities reviewed. According to Chiarini et al (2020) to enhance quality performance in an organisation, it is important to audit the key performance indicators and financial indicators and seek means to control ingenuities for improvement from within. Also, a study by Dardin et al (2020) on the perspectives between internal and external auditors reveals that external auditors are more serious, seeing that they do not work within the organisation which makes it very handy always to have them in Ugandan Municipalities. Consequently, the audit object includes promoting effective control at reasonable cost as well as how the municipal council learns if its internal control systems are appropriately designed and functioning. The key challenges with internal audit are; first, it is perceived to have little to offer and second, the internal auditors have a low status. Also, a study by White et al (2020:108) reveals that boundaries of accountability are unclear due to inadequate audit precautions to guarantee compliance and the participation of internal audit in handling assurance threat did not conform to expert guidance. These challenges call for the audit staff's reasonable assurance, a supportive attitude from both the political wing and the technical wing, integrity and competence. Otherwise, the external audit (Auditor general) attracts more respected by all municipal councils.

\subsection{Conducting staff performance appraisals}

Staff performance appraisal is one of the key instruments in managing staff performance in a municipal council. A municipal council appraises its employee performance regularly in order to define certain areas that require improvement where it is considered in terms of outcomes. A related study conducted among health workers in Hamadan, Iran, Majidi et al (2020) found a significant positive correlation between performance appraisal and job satisfaction. However, there were challenges in terms of futility of assessment statistics for improving performance, the dearth of instant and positive feedback and biased performance assessment. Obtainable evidence indicates that performance appraisal in a municipal council is transparent but not participatory. It does not involve the employee, peers, supervisor and clients except the supervisor and employee. Besides, feedback regarding staff appraisals is not given in time. Also, an appraisal outcome does not lead to any action such as training, transfer, recognition, special awards or disciplinary proceedings.

\subsection{Conducting disciplinary measures}

Municipal councils have been ridden by countless issues arising from political differences and lack of recognition of lower cadres by the top cadres who have built for themselves a sort of canopy. Within the technical wing, insights over classified benefits are reportedly common but rarely addressed by 
department heads. For example, anecdotal evidence confirms evidence of late coming, absenteeism and sexual harassment, which have never been presented to any disciplinary meeting nor has any disciplinary measure ever been taken.

\title{
3. Research methodology
}

The central method for this article is a desk review of obtainable works on accountability in Uganda and other parts of Africa and the world. Desk research is described as the type of research where information is collected from obtainable sources, such as the internet, the press, books, journal articles, methodical and pragmatic reports, and statistical periodicals. According to the Management study guide (2013), desk review is often preceded by cross-referencing and information to make inferences and or conclusions. This method has been recognised to be very supportive and can be applied either in the initial stage of a study project or during the investigation as much of the essential information can be gathered before being used as a stock in the entire study process. This Article is organised along five sections emerging from the questions, namely; section one covers literature review, section two covers the outcomes, and the last section brings forth the conclusion.

\section{Results and discussions}

\subsection{Techniques of enhancing accountability in a Municipal council in Uganda}

There are some ways in which a Municipality can enhance accountability especially as a step towards effective preparation for an oil city that is slated to commence operation in 2021/22 financial year. These are; setting standards, answerability and sanction for errant conduct.

\section{Setting standards}

Standards can be set in the form of behaviour expected of every municipal officer heading a department (HoD) or sector. The criteria by which they might be judged are key. For example, evidence from a municipal council reveals that every $\mathrm{HoD}$ expected to draw a work plan detailing what activities shall be conducted in a particular period of not more than a month and showing the key outputs and resources to be used. These have been a very convenient means of ensuring accountability in a municipal council. A study by Sibanda et al (2020) in a South African Municipality reveals that when successfully executed, the twine measures of control and oversight decrease wastage eliminates moral malfeasance and encourages honesty, transparency, and accountability. Besides, every work plan is accompanied by an activity report at the end of every month indicating whether the planned activities were accomplished, the successes and failures registered and what can be done in the subsequent months to improve service delivery. According to Sibanda et al (2020), there is a need to seek means of reversing the weak application of in-house inventory controls and strategies, making it puzzling for in-house audit and oversight teams to identify unscrupulous, biased, discriminatory, hostile and cost-ineffective actions in time.

\begin{abstract}
Answerability
a process in which the municipal officials are required to defend their actions, face sceptical questions and explain themselves during technical planning committee (TPC) meetings from time to time. According to Kwemarira et al (2019:2) answerability is closely associated with public interest and so this applies to both positive feedback and negative criticisms; these have kept a number of staff on their toes knowing that anytime the TPC sits they will be required to show cause. A municipal council also receives regular funding from government and partners to execute programs and projects outlined in the annual budgets. However, this funding is never adequate. In a number of instances, it has been declining; hence municipal councils in several countries have been forced to shift their responsibilities to the private sector as they, instead, adopt austerity measures (Stick \& Ramos, 2019). As a result, answerability at the department, sector as well as periodic reporting to TPC are key. Finally, there are other mechanisms of answerability involving the general public or part of such as municipal barazas, periodic dialogue with the municipal development forum (MDF) and consultations between the technical wing and the municipal council's political wing.
\end{abstract}

\section{Use of sanction and/or reward}

When the account can be punished for falling below the standards expected of them and or rewarded for achieving or exceeding those standards. A number of Municipalities have been implementing a 
defective sanction system, which has not facilitated the council to build a culture of respect for codes and standards because of the intertwined politics. Anecdotal evidence reveals that there are two camps in the council; when a punishment or reward is administered, it causes higher tempers in the whole council and has previously led to resignation of the chief accounting officer (the Town Clerk). A study by Huang et al (2020) shows rewards lead to psychological empowerment and organisational commitment. Consequently, the punishments seem more like random bad luck for the targets rather than the legitimate consequence of violating or not meeting the standards set. Municipalities have criminal justice sanctions (these follow the criminal justice pattern and trial before courts of law for misuse of principles for cases such as corruption are triable before courts) and the administrative sanctions (where various oversight mechanisms such as administrative tribunals and disciplinary committees are used at the municipal level), which it can administer to errant or excellent individuals.

In short, accountability sequences in Municipalities are not as official and do not include all the aspects mentioned above. Nonetheless, accountability is about how those holding authority can be held openly responsible for their decisions or lack of. This reduces accountability a platform for testing, contesting and transforming a municipal council.

\subsection{Dimensions of accountability in Municipalities in Uganda}

While studies have shown that accountability has both demand and supply sides (Kessy, 2020), is categorised in three dimensions, namely; horizontal, vertical and diagonal.

\section{Horizontal accountability}

This form of accountability encompasses official relationships within a Municipality itself, whereby one municipal actor has the official power to demand details or enforce punishments on another (Almquist, 2012:2). Its emphasis is on in-house checks and balances within the municipal authority. For example, a municipal executive committee must explain its actions to the municipal council and sometimes take precedence or be sanctioned for abusing procedures. Besides, the Auditor General can call for accountability from a municipal council at the end of every financial year. While this demand can, as well, be classified as legal accountability, it is by its nature horizontal. Also, the Public accounts committee of Parliament can demand accountability as part of horizontal accountability between government institutions. According to Mubangizi (2019:557), Municipalities have an obligation to play a part in multifaceted arrangements of horizontal as well as vertical collaboration $\mathrm{s}$ in their quest for effective provision of services to the citizens. Such collaborations demonstrate phenomena of both the complex levels and the complex phases. However, a study conducted in Brazil by Fernandes et al (2020) reveals fragility in horizontal accountability at the subnational level which Ugandan Municipalities may have to contend with.

\section{Vertical accountability}

Vertical accountability involves a situation where citizens and their municipal council play direct roles in holding the powerful to account in the context of performance management system (Tran \& Nguyen, 2020). Elections are the formal institutional channel of vertical accountability. But there are also informal processes through which citizens organise themselves into associations capable of lobbying Municipalities, demanding explanations and threatening less formal sanctions like negative publicity (Rohrer, 2020). A Municipality can conduct barazas or interactive mass media on radios or close dialogue with MDFs as vertical accountability forms. This is in line with the requirement that all public offices and officers shall be answerable to Uganda's people.

\section{Diagonal accountability}

This form of accountability works in a sphere amid the vertical and horizontal dimensions. It denotes the process of direct citizen commitment with horizontal accountability organisations when provoking better oversight of municipal activities (Almquist, 2012:2). According to Modoi (2015), citizens can side-step burdensome or negotiated official accountability structures to engage in policy formulation, participate in budget process, and track the municipal outflow. For example, this platform is commonly used by civil society groups such as Transparency international, Citizen coalition Uganda, Anti-corruption coalition Uganda and the Civil society budget advocacy group which track the budget performance and accountability for public funds that have been allotted to diverse government institutions including Municipalities. 
In delivering pro-poor services, Municipalities draw on intergovernmental relations (IGRs) with the central government. They gain from the oversight role of the central government as well as from the fiscal transfers they receive from the central government - in addition to the considerable oversight function of the Uganda association of urban councils (UAUCs). IGRs in Uganda's Municipalities have sometime been a modus operand in delivering services. Indeed, the Local Governments Act (LGA) (Government of Uganda, 1997) (as amended) states that Municipalities should seek for more innovative methods of not only providing and fast-tracking the delivery of services but remain accountable to the various constituents. In this respect, the LGA on municipal service delivery presents a structure in which to control and organize the funds of the public to meet the overall national development objectives. A number of authors have considered the worth and value of such a structure - see Ferreira (2018).

Municipalities' principal structural arrangement collaborates with other municipal government levels through IGRs and intra-governmental relations - as outlined in the LGA (Government of Uganda, 1997). Since the central government retains the obligation of supervisory oversight, this sets the structure for overall socio-economic progress and the delivery of basic services. The municipal council is expected to fit in this policy structure. Furthermore, the central government arranges much of the funds for service delivery, while the municipal government supervises the implementation of the scheduled programmes as outlined in the national policy agenda. To end, the municipal division sphere is the executing partner of those actions that lie inside the domain of the LGA. Normally, however, policy choices are entrusted to municipal divisions that lack adequate facilitation to deliver the services. Yet, this horizontal relationship is not the only one through which Municipalities operate. There is time and again a cluster of stakeholders, and Municipalities have developed relations with a number of service providers peripheral to them. In such cases, in service delivery, stakeholders like the civil society and the private sector emerge to reduce costs and develop ability for impending subcontracts - this enhances their accountability confidence. At the same time, the image of a municipal council improves.

Maseko and Zaalman (2018:192) underlined a series of abilities vital to Municipalities to improve service delivery, for example, training staff with skills to implement regulations and authorisations, harmonising land tenure systems and improving negotiation abilities so as to enhance compromise as well as accountability. An example where a municipal council can provide accountability is environment and sanitation. A study by Mubangizi (2019) targeted improving service delivery through effective monitoring and evaluation in South African rural Municipalities. It was noted that through collaboration among the three stakeholders, namely Local Government, civil society and the private sector, working together would help moderate a condition in a certain community at the same time the idea of certain actors functioning alone would be reduced thus enhancing the quality-ofservice delivery as well as improving the degree of accountability. Forums such as the MDF in several other Municipalities in Uganda, can play the much-desired oversight role for the shortage of procedural and fiscal abilities and facilitate accountability in a municipal council.

\subsection{The value of accountability to a municipal council in Uganda}

Ugandan Municipalities are confronted with multifaceted and varied challenges as a result of high hopes from the numerous stakeholders to deliver on their obligation. To be more effective in service delivery, accountability is a very essential process that can aid programmes and projects to be executed so that the consequence of these courses will have a significant effect on the projected peoples (Mutabwire, 2013:7). The concept of accountability has been and continue to be emphasised as well as practiced worldwide over the years (Almquist, 2012:2), with the purpose of attaining an effective and sustainable growth; it is key that programmes and projects are well accounted for. Worldwide, there has been amplified burden on administrations and a number of stakeholders to be more accountable relative to how their citizens' aspirations and desires are met through the principles of good governance and be more answerable and transparent so as to uphold efficacy. In consequence, there is a shift to better-quality performance, which has obliged the necessity to account for programmes and projects. As a result, performance is becoming one of the key tools to management used to improve the public sector's actions to support in the achievement of a feasible consequence of development ingenuities in the communities (Modoi, 2015:4). 
Uganda's government has acknowledged the significance of accountability as a necessary programme that could be included in every programme and project write up as an instrument for attaining socioeconomic transformation. This resulted into the formation of the Public accounts committee (PAC) in Parliament as well as every local or urban government, and the directorate of ethics and integrity in the office of the president, charged with the obligation of guaranteeing that the numerous programmes and policies follow to the doctrine of accountability (Modoi, 2015:12). The United Nations development programme (UNDP) describes accountability as the way in which accountability is conducted in Uganda is, to some extent, multifaceted, as a result of the devolution of authority and, per se, not much can be achieved in the Municipalities minus substantial support from the central government. Ogentho, Munene, Kamukama and Mpeera (2020) studied the influence of social capital on the behaviour of citizens and accountability among Local Governments in SSA noting that a deficiency of effective accountability is until now a key challenge which several stakeholders are faced with; one possible alternative is to mobilise the citizens to demand accountability since the consequence is the failure of the numerous programmes and projects to reach the set standards. Consequently, no constructive impact is felt by the numerous publics upon implementation. This is reinforced by how accountability is conducted in Municipalities. Due to the intricacy of accountability in Uganda, it is established that it has not been meaningfully attributable to the absence of political will among the Municipalities' elected representatives, besides a dearth of essential abilities to carry out an effective audit.

Galanti and Turri (2020) note that reliance on the fiscal assets and the partisan salience tends to relegate the municipal councilors' will and the technical staff to seek appropriate options to challenges affecting development. Therefore, one can maintain that imagining struggling Municipalities to obey every requirement of accountability sensibly is as bad as adding hitherto additional accountabilities. Nonetheless, given any mention to accountability, the policy structure is aware of this view. The structure states that seeing that it is a requirement to lessen the harmonisation of managerial accountability across government and that execution achievements should be linked to present abilities aimed to build capacity over the medium-term. This is relevant to Municipalities particularly those that are constrained by a number of challenges. While local potential need not command an enduring model for accountability, the potential of local Municipalities should be included in the operation plans and effective management of any threat.

According to Guevara (2015), Municipalities in much of Africa invented modern methods such as public-private partnerships (PPPs) so as to embrace the private sector in providing municipal services. These stakeholders have connections with one another, which enhances the degree of involvedness favoring dishonesty. Such relationships can be managed and it is this view that has witnessed growing interface between the service providers and service beneficiaries. A web of stakeholders instead of a direct procedure will require more complex accountability modalities that will restrain opportunities for corruption. A number of actions are key in municipal councils and these can favour the delivery of pro-poor services in a number of sub-constituencies in many ways.

The IGRs structure provides a structure for the different spheres of government and every organ of the state to allow coordination in the execution of policies, including accountability to make sure that there is a clear government structure for attaining its objectives. For example, the IGRs within a municipal council serve as an opening for Municipality to participate more effectively in providing an oversight role. The LGA provides that municipal IGR should make sure that there is effective direction and configuration of both the long-term and short-term plans and objectives of a municipal council and any issues that can benefit the communities they serve. However, studies (such as Favero, Gatto, Deutsch \& Pattenella, 2016) reveal that municipal IGRs have not that effective due, in part, to shortage of capacity at the municipal level. One of the most outstanding laws on accountability for Municipalities, is the Local Governments Act (Government of Uganda, 1997), which underscores the details of accountability and the essential aspects that should be taken into account. Furthermore, the Act proposes that Municipalities establish a process of consistent reporting on accountability so as to the council, the technical planning committee, standing committees, the MDF and the public through local radio talk shows. 


\subsection{Implications of accountability for pro-poor service delivery in a municipal council}

The central description evolving from the accounts of this article, is that. In contrast, ill resourced rural Municipalities are likely to benefit from robust methods of accountability, there are, at present, insufficient procedures being trailed by Ugandan Municipalities and this might be resulting from scarcity of essential skills. As the debate has revealed, this is attributable to the scale of regulation that either disregards or overshadows the municipal council's will and its technical managers to seek inventive local options to local challenges. The debate has revealed that cooperation between a municipal council and various stakeholders in a self-organising way, seems to be budding as a muddle through instrument in a municipal council. The opinion, here, is to be acquainted with intricacy and absence of linearity in the delivery of services and consequently seek out means to incorporate aspects at more than one level and sequential gauge. From the debate, the ensuing propositions are advanced:

First, the ultimate structure should yield info appropriate to a rural Municipality while being consistent and appropriate enough to advise and effect procedures for preparation and implementation. Second, a model structure of accountability grounded on the viable livelihood arrangement necessitates complete information that cross-examines all five aspects of the agenda and procedure and other official procedures of municipal governance (Mulgan, 2017). Third, a municipal council should continue to be an essential participant so that there is navigation from the external with track from the internal seeing that the multifaceted structure is at probabilities with the design of explicit objectives and plans to inform the situation of pro-poor service delivery. Finally, a supreme structure of accountability should have operative instruments for presenting accountability to a diversity of stakeholders, who, characteristically, consist of the elected (politicians), the appointed (technical staff) and the residents (beneficiaries).

\section{Conclusion}

This article examined how accountability is executed in a Ugandan Municipality for resolves of efficiently delivering pro-poor services. It is observed that the concern of accountability in Uganda remains attracting substantial consideration, as a result of its significance in supporting Municipalities and other entities of government to accomplish their mandate of enhancing wealth creation. A municipal council needs the participation of a variety of stakeholders working in a multifaceted system to attain its mandate is an additional goal why the processes of accountability require to be prioritised above board. Above all, the structures of accountability should be easy to get to for diverse users; they should be hands-on as well as endearing for both the beneficiaries and the service providers. The present process of accountability in Municipalities is primarily executed through constitutional structures whose operative rules are outlined in a variety of municipal government laws and guidelines. Although these are essential and helpful, this article's debate has revealed that nonconstitutional arrangements shaped out of improvised self-organising approaches can deliver advantageous pro-poor service delivery opportunities. It is exposed, without thorough accountability procedures, through an all-embracing strategy, with participation from numerous participants at the diverse levels of government as well as local communities, together with development of skills and political will, endeavours of accountability will continue to be one of the disappointments, with the prospective to further relegate municipal councils in the country. To sum up, hands-on accountability holds potential in this regard, and requires more consideration as a means to assimilate learning-based methods as well as role-players network to back up the delivery of pro-poor services.

\section{References}

Almquist, R. (2012). Public sector governance and accountability. Critical perspectives on accountability. Accessed DOI: 10.1016/jcpa.2012.11.005.

Bidandi, F., and Williams, J.J. (2017). The terrain of urbanisation process and policy frameworks: A critical analysis of the Kampala experience. Cogent social sciences, 3(1).

Birungi, C., and Colbourn, T. (2019). It's politics, stupid! A political analysis of the HIV/AIDS Trust Fund in Uganda. African journal of AIDS research, 18(4). 370-381.

Bolgherini, S., Dallara, C., and Profeti, S. (2019). A shallow rationalisation? 'Merger mania' and sideeffects in the recognisation of public-service delivery. Contemporary Italian politics, 11(2). 112-136. 
Bryld, E., Kamau, C., and Mahamoud, M.A. (2020). Using an adaptive approach to making gatekeepers accountable t internally displaced persons in Mogadishu, Somalia. Development in Practice. Accessed DOI: 10.1080.09614524.2020.1754765.

Casady, C.B., Eriksson, K., Levitt, R.E., and Scott, W.R. (2019). (Re)-defining public-private collaborations (PPPs) in the new public governance (NPG) paradigm: an institutional maturity perspective. Public management review. Accessed DOI: 10.1080/14719037.2019.157790.

Chiarini, A., Castellani, P., Rossato, C., and Cobelli, N. (2020). Quality management internal auditing in small and medium-sized companies: an exploratory study on factors for significantly improving quality performance. Total quality management \& business excellence. Accessed DOI: $10.1080 / 14783363.2020 .1776101$.

Choge, P.J., Chepkiyeng, F., and Chelimo, K.K. (2014). Effects of task identity on employee motivation: a survey of Eldoret polytechnic, Kenya. European journal of business and management online.

Dardin, F.D., Medeiros, C.O., Diz, M.N., Da Costa, R, L., and Stangarlin-Fiori, L. (2020). Evaluation of god hygiene practices in food trucks from the perspective of internal and external auditors. Journal of quality assurance in hospitality \& hospitality. Accessed DOI: 10.1080/1528008X.2020.1756023.

Eastwood, R., and Lipton, M. (2011). Demographic transition in sub-Saharan Africa: how big will the economic dividend be? Population studies, 65(1). 9-35.

Favero, M., Gatto, P., Deutsch, N., and Pettenella, D. (2016). Conflict or synergy? Understanding interaction between municipalities and village commons (regole) in polycentric governance of mountain areas in the Veneto region, Italy. International journal of the commons, 10(2).82153, retrieved from https://www.jstor.org/stable/26522889

Fernandes, G.A.L., Teizeira, M.A.C., Fernandes, I.F.L., and Angélico, F. (2020). The failures of horizontal accountability at the subnational level: a perspective from the global south. Development in practice. Accessed DOI: 1080.09614524.2020.1773764.

Ferreira, G.M. (2018). Gender responsive budgeting in the Cape Agulhas Municipality. Administratio Publica. 26(2). 23-42.

Galanti, M.T., and Turri, M. (2020). Accountability in local public utilities: not only corporate governance. International journal of public administration. Accessed DOI: 10.1080/01900692.2020.1739075

Government of Uganda. (1997). The local governments act. UPPC: Entebbe - Uganda.

Guevara, A. (2015). Public-private partnerships: an innovative solution for a declining infrastructure. The urban lawyer, 7(2).309-28. Retrieved November 17, 2020, fromhttps://www.jstor.org/stable/26425547

Huang, Y., Liu, H., and Huang, L. (2020). How transformational and contingent reward leaderships influence university faculty's organisational commitment: the mediating effect of psychological empowerment. Studies in higher education. Accessed DOI: 10.1080.03075079.2020.1723534.

Kassem, R. (2019). Understanding financial reporting fraud in Egypt: evidence from the audit field. Third world quarterly. 40(11), 1996-2015.

Kayiwa, D., Mselle, J.S., Isunju, J.B., Ssekamate, T., Wafula, S.T., Muleme, J.S., Ssempebwa, J., Namanya, E., Bateganya, N.L. Yakubu, H., and Mugambe, R.K. (2020). Determinants of hygiene practices among mothers seeking delivery services from healthcare facilities in the Kampala metropolitan area, Uganda. International journal of environmental health research. Accessed DOI: 10.1080/09603123.2020.1755015.

Kessy, A.T. (2020). The demand and supply sides of accountability in Local Government authorities in Tanzania. Public integrity. DOI.10.1080.1099922.2020.1739361.

Kwemarira, G., Ntayi, J.M., and Munene, J.C. (2019). Accountability and public interest in government institutions. International journal of public administration. Accessed DOI: 10.1080/01900692.2019.1672187.

Majidi, S., Daneshkohan, A., Zarei, E. and Ashktorab, T. (2020). Perspectives of health workers on annual performance appraisal: a study in primary healthcare. International journal of healthcare management. Accessed DOI: 10.1080/20479700.2020.1755810. 
Management study guide (2013). Desk research - methodology and techniques. Accessed from http://managementstudyguide.com/desk-research.htm. (retrieved 12 January 2021)

Maseko, M. and Zaalman, J. (2018). The Simdlangentsha traditional council and Local Government: towards an improved relationship. Administratio Publica, 26(2).175-197.

Mbazira, C. (2013). Service delivery protests, struggle for rights and the failure of local democracy in South Africa and Uganda: parallels and divergences. South African journal of Human Rights, 29(2), 251-275.

McConville, J.R., Kvarnstrom, E., Maiteki, J.M., and Niwagaba, C.B. (2019). Infrastructure investments and operating costs for faecal sludge and sewage treatment systems in Kampala, Uganda. Urban water journal, 16(8).484-593.

Mir, F.A., Rezania, D., and Baker, R. (2020). Managing change in pluralistic organisations: the role of normative accountability assumptions. Journal of change management, 20(2).123-145.

Modoi, M. (2015). Promoting accountability in JLOS: Concepts and strategies. Justice Law and order sector, Kampala.

Mubangizi, B.C. (2019). Monitoring and evaluation processes critical to service provision in South Africa's rural-based Municipalities. Journal of reviews on global economics, 8, 555-565.

Mulgan, R. (2017). Accountability in multi-level governance: the example of Australian federalism. In Daniell, K., and Kay, A. (Eds.). 'Multi-level governance: conceptual challenges and case studies from Australia' (pp.81-100). Australia: ANU Press. Retrieved November 17, 2020, from http://www.jstor.org/stable/j.ctt1zgwjv0.9 mm

Musenze, I.A., and Mayende, S. (2020). Development and validation of a total quality management model for Uganda's Local Governments. Cogent business \& management, 7(1). Accessed DOI: 10.1080/23311975.2020.1767996.

Musenze, I.A., Munene, J.C., Ntayi, J.M., and Balunywa, W. (2014). Communication and quality service delivery in Uganda's Local Government: the mediating influence of total quality management. African journal of science, technology, innovation and development, 6(2), 93103.

Mutabwire, P. (2013). Principles of service delivery in Uganda's Local Governments. Ministry of Local Governments, Kampala.

Mwesigwa, D., and Mubangizi, B.C. (2015). Citizen Participation and policy formulation: A study of bottom-up, top-bottom, and horizontal scenarios in local councils in western Uganda. Journal of Administratio Publica, 23(4). 13-29.

Mwesigwa, D., and Mubangizi, B.C. (2018). Implementation of the Uganda Support for Municipal Infrastructural Development for Smart Cities: a survey of Hoima Municipality. Loyola Journal of Social Sciences, XXX (2). 65-86.

Nastar, M., Isoke, J., Kulabako, R., and Silvestri, G. (2019). A case for urban liveability from below: exploring the politics of water and land access for greater liveability in Kampala, Uganda. Local environment, 24(4). 358-373.

Nattabi, A.K. (2020). Can Uganda afford new Local Government administrative units? Economic policy research centre, Kampala.

Ogentho, P.M., Munene, J.C., Kamukama, N., and Ntayi, J.M. (2020). Citizens' behaviour and accountability: the power of social capital in sub-Saharan African local governments. International Journal of Public Administration. Accessed DOI: $10.1080 / 01900692.2020 .1729186$

Rohrer, I. (2020). Informal accountability. Street-level bureaucrats' tactics to defy bad reputation in agencies of the Argentinian justice system. Oxford development studies. Accessed DOI. 10.1080/13600818.2020.1787368.

Sibanda, M.M., ZIndi, B., and Maramura, T.C. (2020). Control and accountability in supply chain management: evidence from a South African metropolitan Municipality. Cogent Business \& Management, $7(1)$.

Steinbach, A. (2019). EU economic governance after the crisis: revisiting the accountability shift in EU economic governance. Journal of European public policy, 26(9), 1354-72.

Stick, M., and Ramos, H. (2019). Does municipal funding of organisations reflect communities of need? Exploring trends in Halifax, 1996-2016. Urban Research \& Practice. Accessed DOI: 10.1080/17535069.2019.1705382. 
Su, W., Lyu, B., Liu, Y., Chen, H., and Fan, J. (2019). Supervisor developmental feedback and employee performance: the roles of feedback-seeking and political skill. Journal of Psychology in Africa, 29(5), 435-442.

Tran, Y.T., and Nguyen, N.P. (2020). The impact of the performance measurement system on the organisational performance of the public sector in a transition economy: is public accountability a missing link? Cogent Business \& Management, 7(1).

UN Habitat 2015. The challenge of local government financing in developing countries.

White, S., Bailey, S., and Asenova, D. (2020). Blurred lines: exploring internal audit involvement in the local authority risk management function. Public Money \& Management, 40(2), 102-112.

$\mathrm{Wu}$, S., and Christensen, T. (2020). Corruption and accountability in China's rural poverty governance: main features from village and township cadres. International Journal of Public Administration. Accessed DOI: 10.1080/01900692.2020.1765799.

Zhou, T., and Cai, J.X. (2020). How the exposed are disciplined? Media and political accountability in China. Journal of Contemporary China, 29(122), 286-303. 